\title{
Bridging Knowledge Divides: The Case of Indigenous Ontologies of Territoriality and REDD+
}

\section{Highlights}

- New relationships are needed among indigenous peoples and researchers in order to co-produce knowledge to tackle global challenges.

- Comparing and sharing knowledge across knowledge traditions can create opportunities to develop new approaches to addressing deforestation, forest degradation and climate change more generally.

- Much is at stake as we move into the Paris Agreement implementation phase, where it is clear that 2 or even 1.5 degrees warming limitations cannot be achieved without the meaningful participation of non-state actors, including indigenous peoples and their different bases of knowledge.

- We identify three approaches through which indigenous ontologies on territoriality are relevant in their local context. These approaches could be scaled up and related to REDD+ across levels of governance; their holistic practices could be interpreted as guiding principles for improving forest management.

- Approaching REDD+ through the perspective of indigenous territoriality is not only about protecting forests from deforestation and forest degradation, but also about defending the integrity of peoples who have sustainably coexisted in and with their forests by means of a worldview that promotes a reflective practice on reciprocity between human and natural worlds.

\begin{abstract}
This study examines traditional indigenous ontologies of territoriality based on a number of indigenous communities in Bolivia and Colombia to show how they can inform effective implementation of REDD+ (Reducing Emissions from Deforestation and forest Degradation plus sustainable forest management, forest conservation and enhancing forest carbon stock). This could help address concerns that REDD+ interventions oversimplify local dynamics and complexities. The concept of territoriality subsumes a variety of definitions and conceptions, some of which are embedded in Traditional Ecological Knowledge and represented in the multiple
\end{abstract}


expressions of collective indigenous identity. We compare and contrast Western and indigenous ontologies of territoriality and identify three ways in which engagement with territoriality can enhance REDD+ implementation and effective non-state actor participation.

Key words: Indigenous peoples; territoriality; deforestation; REDD+ governance; Bolivia; Colombia

\section{Introduction}

The main approach to addressing deforestation and forest degradation has been REDD+ (Reducing Emissions from Deforestation and forest Degradation plus sustainable forest management, forest conservation and enhancing forest carbon stock) under the United Nations Framework Convention on Climate Change (UNFCCC). Since its inception in 2007 it has led to significant changes in discourses, practices, policies and legal frameworks across forest territories in the developing world (Angelsen et al. 2012, Mulyani and Jepson 2013, Luttrell et al. 2014). Whilst REDD+ has contributed to increased non-state actor engagement in international climate change governance (Brockhaus et al. 2014, Gupta et al. 2016, Betts and Schroeder 2015, Newell et al. 2012, Nasiritousi et al. 2016), it has been slower in recognising the ecological knowledge and practices of inhabitants of forests that have historically maintained the balance and well-being of these ecosystems (Posey 1985, 2002, Kawagley and Barnhardt 1998). The literature on REDD+ also points to repeated cases of oversimplified and generalised understanding of local level dynamics and complexities, leading to adverse outcomes and a tendency to not align project goals with local needs and relationships with their territory (Corbera and Schroeder 2017, Gebara and Agrawal 2017, Trædal and Vedeld 2017).

The occupation of indigenous territories since colonial times has led to the emergence of asymmetric powers and intense struggles for territorial control (Gilbert 2006, Peluso 1996, McGregor 2002). In most Latin American countries, indigenous cultural traditions and traditional struggles are intimately linked to the land (Toledo 2002, Rappaport 2005). Indigenous territories have been systematically colonized (absorbed) by state institutions, illegal actors and foreign investors (Van Cott 2000, Smith 2013, Peluso 1998). However, many indigenous communities strive to maintain 
a balanced and respectful relationship with natural resources and their territory; this undertaking by no means aims to increase capital or its accumulation (Deloria 1969, Gilbert 2006). During the 19th Century, the governments of many Latin American countries used such non-accumulation practices to their advantage by declaring indigenous territories terra nullius ("empty lands") and stripping native populations of their capability of self-determination (Gilbert 2006, Tuhiwai Smith 2013). In Colombia, Law 89 of 1890 recognized indigenous territories under the guardianship of the Catholic Church because it considered indigenous peoples as "underaged" and this unable to unable to hold "adult" legal rights and responsibilities (Ortega 2000). Similar laws existed in: Guatemala (1839), Ecuador (1830) and Mexico (1940) (Ibídem). As a result, many indigenous nations lost their sovereignty over their traditional territories and became subordinated by the new owners (Deloria 1969, Rappaport 2005).

In the last decades, a number of government regulations across Latin American countries have recognized territorial rights of indigenous peoples, which has led to national and international courts effecting the return of lands to their previous owners (Gilbert 2006). Such rights are also being pursued at the international climate negotiations, where indigenous representatives are calling for a recognition of their "spirituality, territoriality, governance related to self-determination, and full sovereignty over their own economy and traditional knowledge" (Interview with Latin American indigenous peoples representative, Bonn 2013).

Forest communities continue to be politically and economically marginalized and vulnerable to foreign activities encroaching upon their traditional ways of life (Gilberthorpe and Rajak 2017). In addition, they are vulnerable to the effects of climate change. Yet, indigenous forest conservation mechanisms have had a significant positive impact on biodiversity preservation around the world. Evidence from satellite modelling shows that 80 percent of the planet's biodiversity can be found in indigenous territories, 11 percent of which are in indigenous community ownership (Sobrevila 2008).

For indigenous peoples, territoriality is linked to self-determination (Mcgregor 2002, Tuhiwai Smith 2013, Deloria 1969) in that their traditional sustainable forest practices connect culture with nature and their collective identity aims to maintain the balance of ecosystem services, but also their material well-being keeping a sustainable perspective in the long term (Lajó 2006, Lee 2016). This knowledge is 
typically dismissed in Western science and policy circles as "unqualified, biased or 'not scientific enough"” (Diver 2017,4). More work is needed to communicate and reconcile such different values, norms and worldviews. As noted by a Latin American indigenous peoples representative, "we all have the obligation to change the way we are living, producing and consuming. I think that the climate change discussion is one of the few chances we have to put it all on the table. We are indigenous people, we have very different issues and different conscience, and different way of contributing with our knowledge" (COP-20, Lima, 2014).

Attempts to give voice to different values, norms and worldviews certainly exist. For example, the Intergovernmental Science-Policy Platform on Biodiversity and Ecosystem Services (IPBES) aims to provide policymakers with relevant knowledge on how to bridge the gap between indigenous knowledge and scientific knowledge (Löfmarck and Lidskog 2017) and the project Earth System Governance (ESG) recognizes the need for a paradigmatic change in governance to cope with fundamental transformations of the earth system, interconnecting and integrating all levels of governance and enabling formal and informal (state and non-state) policy actors to play their parts (Biermann et al. 2010).

Ten years of REDD+ activities demonstrate the relevance of local knowledge and participation to enhance successful outcomes. We tackle the case of indigenous ontologies on territoriality and REDD+, exploring how the traditional knowledge present in their practices can be scaled up to contribute to more legitimate forest governance and more holistic approaches to forest management. This article is structured as follows: After a description of the methodology, the article contextualises indigenous peoples' rights and REDD+ governance. It then compares and contrasts Western and indigenous understandings of territoriality before applying indigenous ontologies of territoriality to REDD+ and proposing concrete ways in which the former can inform the latter.

\section{Methodology}

Our interpretative analysis focuses on a practice-based approach to forest governance, understanding practice to be a part of governing. The meaning of practice is articulated through political dynamics, for example the influence of non-discursive and material aspects of land use in a Chagra (i.e., a traditional agricultural itinerant cultivation area of indigenous communities in Bolivia and Colombia) and where 
effective decisions on shared concerns relating to forest and biodiversity conservation, food security and adequate land use are taken (Art et al. 2013, Krott and Giessen 2014, Behagel et al. 2017). This approach also offers insight into how institutional structure affects practice and how local agents respond to them. We address the need for a more balanced interaction between politics and institutions with indigenous notions of forest sustainability. There are three sensitive concepts that frame this analysis: 1) logic of practice, 2) situated agency and 3) performativity (Krott and Giessen 2014, Behagel et al. 2017). We reflect on how this knowledge of territoriality roots and contextualizes local experiences and traditional knowledge of indigenous peoples, but also how these interpretation of practices (as land use in a Chagra, identification of key species, crop mixture and territorial boundaries through mental mapping) can contribute to the definitions of guiding principles for a more holistic approach to forest governance.

Our interpretative analysis identifies bodies of knowledge present in traditional ecological practices, seeking for their incorporation as guiding principles for global mechanisms as well as a more enlightened picture of the realities of forestdependent communities (Smith 2008, Kovach 2010, Deloria 1969, Nadasdy 2005). We refer to Traditional Ecological Knowledge (TEK) and Integrated Local Environmental Knowledge (ILEK) to incorporate local practices into REDD+ implementation. To do so, we offer three ideas on how this could be done in practice.

This research analyses primary and secondary literature to identify commonalities among indigenous communities Bolivia and Colombia with regard to their understanding of territory and territoriality in the context of REDD+ governance. Primary sources include policy briefs, official documents, project reports and media analyses of the societal and institutional contexts. They offer a detailed picture of landscapes, images, perceptions and stories about indigenous ontologies and practices of territoriality in Colombia and Bolivia. Secondary literature from a number of disciplines, including political science, anthropology, law and geography as well as publications on ethnopedology and ethnoecology in Latin American indigenous communities, are also included.

This study uses two sets of interview and participant observation data. Table 1 gives an overview of the first set of interviewees who contributed to original data collected in a number of sites in Colombia and Bolivia. It includes 53 semi-structured interviews carried out with indigenous representatives in Colombia in the periods 
February 2003-July 2009 and June-July 2017, during research visits to the communities of the Nasa, Guambianos, Ingas, Kamsa and Nonuya in the Cauca, Vaupes and Putumayo regions in Colombia. Also eight semi-structured interviews and participant observation were carried out in Bolivia in August 2009 with the indigenous groups Mojeños, Yucarares and Quechuas.

Table 1: Overview of interviews in Bolivia and Colombia

\begin{tabular}{|c|c|c|c|c|}
\hline Role in the community & Organizational affiliation & $\begin{array}{l}\text { Interview } \\
\text { date }\end{array}$ & $\begin{array}{l}\text { Number of } \\
\text { interviewee } \\
\text { S }\end{array}$ & $\begin{array}{l}\text { Indigenous } \\
\text { citizenship }\end{array}$ \\
\hline $\begin{array}{l}\text { Indigenous } \\
\text { Community } \\
\text { representative with } \\
\text { responsibility in any of } \\
\text { their official program }\end{array}$ & $\begin{array}{l}\text { Asociación de Cabildos Indígenas del } \\
\text { Norte del Cauca ACIN, Municipalities } \\
\text { Toribío, Tacueyó, San Francisco, El } \\
\text { Palo, Popayán, Centro comunitario el } \\
\text { Guabito, Consejo Regional Indigena del } \\
\text { Cauca CRIC, Organización Nacional } \\
\text { Indígena de Colombia, ONIC, } \\
\text { Organización Pluricultural de Pueblos } \\
\text { Indígenas de Colombia, OPIC }\end{array}$ & $\begin{array}{l}2003 / 2009 \\
\text { and } 2017\end{array}$ & 22 & Yes \\
\hline \begin{tabular}{|l|} 
Indigenous \\
Community \\
representative with \\
responsibility in any of \\
their official program
\end{tabular} & $\begin{array}{l}\text { Confederación de Pueblos Indígenas de } \\
\text { Bolivia, CIDOB, Consejo Nacional de } \\
\text { Ayllus y Arkas del Qullasuyu, } \\
\text { Federación Nacional de Mujeres } \\
\text { Campesinas de Bolivia "Bartolina Sisa", } \\
\text { Movimiento al Socialismo }\end{array}$ & 2009 & 8 & Yes \\
\hline $\begin{array}{l}\text { Coordinator or official } \\
\text { of the indigenous } \\
\text { organisation }\end{array}$ & $\begin{array}{l}\text { Programa Intercultural, Planeación, } \\
\text { Program de Etnoeducación Bilingüe } \\
\text { PEBI, Programa de comunicaciones del } \\
\text { CRIC }\end{array}$ & $2003 / 2005$ & 7 & No \\
\hline \begin{tabular}{|l|} 
Leader or member of \\
indigenous \\
organisation for young \\
people
\end{tabular} & $\begin{array}{l}\text { Movimiento Juvenil, Programa } \\
\text { Animadores comunitarios, Nietos de } \\
\text { Quintín, }\end{array}$ & & 4 & \\
\hline Traditional Elder & Nasa, Kankuamo, Noyuna, Aruahaco & $\begin{array}{l}\text { Permanent } \\
\text { position }\end{array}$ & 4 & \\
\hline $\begin{array}{l}\text { National coordinator } \\
\text { Program for Bilingual } \\
\text { and Intercultural } \\
\text { Education } \\
\end{array}$ & National Ministry of Education MEN & & 1 & Yes \\
\hline $\begin{array}{l}\text { Consultant for } \\
\text { governmental } \\
\text { institution (Colombia) } \\
\text { related to indigenous } \\
\text { issues }\end{array}$ & $\begin{array}{l}\text { Unidad de Políticas para las Minorías } \\
\text { Étnicas del Departamento Nacional de } \\
\text { Planeación DNP, Asuntos Étnicos de la } \\
\text { Procuraduría de la Nación, Departamento } \\
\text { Asuntos Indígenas Ministerio del } \\
\text { Interior, Sistema de Áreas Protegidas de } \\
\text { la Subdirección de Parques del Sistema } \\
\text { Nacional de Parques, Ministerio del } \\
\text { Medio Ambiente }\end{array}$ & 2004 & 11 & No \\
\hline $\begin{array}{l}\text { Academic people } \\
\text { studying indigenous } \\
\text { questions } \\
\end{array}$ & $\begin{array}{l}\text { Universidad Nacional de Colombia, } \\
\text { Universidad Mayor de San Andrés }\end{array}$ & & $\beta$ & \\
\hline $\begin{array}{l}\text { Responsible for ethnic } \\
\text { issues of International } \\
\text { organisations and }\end{array}$ & $\begin{array}{l}\text { United Nations Educational, Scientific } \\
\text { and Cultural } \\
\text { Organization(UNESCO),United Nations }\end{array}$ & & 6 & \\
\hline
\end{tabular}




\begin{tabular}{|l|l|l|l|}
\hline NGOs & $\begin{array}{l}\text { Development Programme (UNDP), } \\
\text { Swiss Program for Peace development in } \\
\text { Colombia (Suipcool), Tropenbos, GAIA, } \\
\text { Instituto Humboldt }\end{array}$ & & \\
\hline
\end{tabular}

The second set of data comes from research undertaken at the UNFCCC Conferences of the Parties (COPs) in Doha (2012), Warsaw (2013) and Lima (2014) and meetings of the UNFCCC Subsidiary Bodies in Bonn during the period 2013-2015. This included seven semi-structured interviews with indigenous representatives, observation of meetings of the Indigenous Peoples Organisations constituency and attendance at side events and Forest Days/Global Landscape Days featuring indigenous peoples' representatives.

Semi-structured interviews with indigenous interviewees focused on their perceptions of territory and the ways in which they characterize meaningful (traditional) practices as common routines in their territories, particularly identifying guiding principles which rule their territorial relations. In interviews with experts/ leaders, participants were invited to reflect on the meaning of their practices for the maintenance of forest resources. Interviewees were asked about their understanding of sensitive concepts about their territoriality (logic of practice, situated agency and performativity). Interviews with indigenous representatives at the UNFCCC COPs and SBs focused on the process of negotiating and establishing new institutional relations for the acknowledgment of self-determination of indigenous peoples in REDD+, as well as highlighting ILO and UNDRIP conventions during COP negotiations.

\section{Indigenous peoples' rights and REDD+ governance}

Many indigenous peoples have been in a long-standing struggle to maintain their cultural, spiritual, political and economic ties to their traditional territories, most recently due to large-scale extractive activities (Hall 2013, Papyrakis et al. 2017). In this context, some indigenous organisations and activist groups have asserted that REDD+ is the newest version of an old type of policy that, through international markets and neoliberal mechanisms, continues to impede their quest for selfdetermination and self-realisation (Cabello and Gilbertson 2012). Others are starting to express interest in REDD+ and carbon markets as an opportunity to defend their resources and territories (Salick and Byg 2007, Harada et al. 2015). 
Much has been achieved in terms of institutionally recognising indigenous peoples' rights over the last several decades. Mechanisms and agreements that acknowledge the indigenous populations include the Working Group on Indigenous Populations (1985), the Indigenous and Tribal Peoples Convention (ILO 169) (1989), Agenda 21 (1992), the Rio Declaration on Environment and Development (1992), the UN Statement of Principles for the Sustainable Management of Forest (1992), the UN Special Rapporteur on Indigenous Communities, Peoples and Nations, the International Decade for World Indigenous Peoples (2004) and the UN Declaration on the Rights of Indigenous Peoples (UNDRIP 2007) (Van Cott 2001, González 2011). These are now taken note of in the international climate negotiations.

During the 1990s, many constitutions of Latin American countries have undergone reforms (Guatemala (1986), Brasil (1988, 1994, 1997), Chile (1989, 1994, 1997), Colombia (1991), Costa Rica (1996, 1997), Dominican Republic (1996), Ecuador (1996,1998), Mexico (1994, 1995), Nicaragua (1987, 1995), Panama (1994), Paraguay (1992), Peru (1993), Bolivia and Argentina (1994) and Uruguay (1997)) to establish plurinationalism with multicultural and ethnic rights, which has led to increased indigenous political participation and rights for minorities (Van Cott 2000), both nationally and internationally. As highlighted by a Latin American indigenous representative, interviewed at COP-14 in 2013 in Warsaw, "some delegates are very well involved, they have very well language on indigenous people - what kind of rights we have in the United Nations, what kind of declarations of rights we have in the international arena". However, full implementation of these rights still requires more shifts in political practices at national and international levels (Griffiths 2008, Inman 2015).

It has been noted that REDD+ could be aligned more explicitly with international conventions that seek to advance indigenous self-determination in their territories (Abidin 2015, Craig 2015, Perrin 2018). The ILO Convention No. 169 (Convention concerning Indigenous and Tribal Peoples) affirms indigenous peoples' rights to retain their customs and institutions (ILO No. 169, supra note 60, Art. 8(2), Inman 2015), thus recognising legal pluralism (Anaya 2004). Articles 6 and 7 recognize the collective use of land and its collective property and provide a foundation for such co-production and co-management arrangements (ILO 2013). In its Article 7(3), the convention emphasizes the need for studies assessing the social, spiritual, cultural and environmental impacts on indigenous communities from 
planned development activities (ILO 2013). The convention stipulates in Article 15 that indigenous peoples have a right to use, manage and conserve natural resources pertaining to their lands (ILO 2013, Anaya 2009). The UNDRIP declaration reinforces indigenous territoriality by advocating that states cooperate with traditional authorities to develop, understand and use natural resources, recognize and protect indigenous territories and respect their beliefs and land tenure systems adjudicating rights pertaining to their territoriality, and that indigenous representatives participate in this process (Inman 2015, Hanna and Vanclay 2013, Butzier and Stevenson 2015).

The intention to avoid adverse outcomes from REDD+ projects at local level has led some NGOs and governments to push for social safeguards as part of any REDD+ activity (McDermott et al. 2012, McDermott and Ituarte-Lima 2016, Dehm 2016, Luttrell et al. 2013). A set of seven safeguards were adopted in Cancun in 2010, including "respect for the knowledge and rights of indigenous peoples and members of local communities" and the "full and effective participation of relevant stakeholders, in particular indigenous peoples" (UNFCCC 2010, Krause et al. 2013, McDermott et al. 2012, Wallbott 2014). Such practice is not yet the norm, however.

The marginalisation of indigenous peoples through Western policies has led to a dominant view in international policy interventions of indigenous peoples as victims. To avoid such potential outcomes from REDD+ projects, some NGOs, international organisations and donors have pushed for social safeguard programmes that address the rights of indigenous communities and other forest-dwelling peoples, including swidden agriculturalist, permanent small-scale farmers and ranch operators (Thompson et al. 2011). REDD+ legitimacy is delivered by an institutional design and implementation that is transparent, inclusive and accountable (Corbera and Schroeder 2011, Glover and Schroeder 2017). The REDD+ safeguards are meant to ensure these principles are observed. Alongside the do-no-harm objective of safeguards, REDD+ projects often also state do-good objectives, articulated through social and ecological co-benefits, such as poverty alleviation, watershed protection and biodiversity conservation (McDermott et al. 2012, Chapman et al. 2014).

Some bottom-up approaches have focused on including democratic, decentralized and transparent forest governance structures during decision-making and implementation procedures. Moreover, they have focused on supporting mechanisms about rights and participation of indigenous peoples and local communities in REDD+ (McDermott et al. 2012, McDermott and Ituarte-Lima 2016). 
In Latin America, many indigenous representatives have also called for comanagement agreements (McDermott and Ituarte-Lima 2016), for example adaptive co-management initiatives that bring together ecological knowledge and sustainable forest management to achieve better adaptation outcomes (Berkes et al. 2003, 2004, 2006, Tompkins and Adger 2004). Despite the legal acknowledgement of indigenous rights, policymakers have not necessarily been able to make sense of indigenous territoriality, for example regarding the effectiveness of their practices in protecting biodiversity regard for self-determination and the important role of their territory in their collective identity (Gross and Foyer 2010).

The UN-REDD programme has a reputation for addressing the participation of indigenous and forest-dependent people in a rather top-down manner without meaningfully considering the voices of stakeholders (Thompson et al. 2011). The World Bank's Forest Carbon Partnership Facility (FCPF) approach to enlisting participation in REDD+ activities has been critiqued in the past for its lack of involvement of indigenous peoples and other forest dependent groups (Davis et al. 2009). However, it is possible that without World Bank standards there would have never been REDD+ safeguards in the first place. Most UN-REDD and FCPF policy documents treat the state as the principal apparatus for implementation of REDD+ projects (Thompson et al. 2011). This emphasis on the national level has led to concerns regarding the recentralization of forest governance and possible state-led 'green' land grabs (Osborne et al. 2014, Holmes 2014). Also, Monitoring, Reporting and Verification (MRV) frameworks require critical revision given that current evaluations of REDD+ identify the need of using measurements appropriate to local realities in order to evaluate the quality of the local environment and improvements in REDD+ implementation (Angelsen et al. 2012, Armenteras et al. 2016).

\section{Comparing Western and indigenous ontologies of territoriality}

The term territoriality has been used extensively in forest governance literatures to characterize dynamics and relationships among different forest users. It has been described as a resource management system and a behavioural self-regulatory mechanism (Berkes 2012), applied to analyses of strategies for controlling access to land and resources through state forests (Vandergeest and Peluso 1995, Sack 1983) and to describe dynamics of forest control in protected and conservation areas (Corson 2011, Holmes 2014). All territories are subject to territorialisation processes. 
In this sense, territories are living places and territorialisation is the process that happens between territory and territoriality, whilst territoriality comprises the interrelational processes where different actions - affecting, influencing, controlling, interacting or asserting - take place in a defined area (Sack 1983).

There are a number of overlaps between indigenous and Western notions of territoriality, but at the same time there are certain qualities that belong specifically to the indigenous ontologies on territoriality. First, territoriality as a subjective characterization of understanding space under certain circumstances. Whilst indigenous ontologies refer to their territory as a holistic, integrated system made of interconnected dynamics (ever-changing natural forces), Western ontologies understand territory as compartmentalized or fragmented (Lajó 2006, Barnhardt and Kawagley 2005, Kawagley and Barnhardt 1998, Lee 2016).

Second, indigenous and Western territoriality define boundaries to separate themselves from other groups. The indigenous mapping of boundaries in their territories promotes a reflective practice on recognizing reciprocity between human and natural worlds (Fox-Decent and Dahlman 2015, Deloria 1969).

Third, in both ontologies territoriality can enforce control on the time-space distribution of resources, and authorities are responsible for the definition of the corresponding rules and sanctions (Vieco et al. 2000). Regarding the indigenous view, the role of humans is to participate in the orderly design of nature, as the proper human-nature relationship represents a continuous two-way and transnational dialogue (Barnhardt and Kawagley 2005, Kawagley and Barnhardt 1998).

Fourth, territoriality in Western and indigenous ontologies provides a means of reifying power, i.e. making potential or tangible power explicit. Indigenous groups make their territorial power visible when communicating and legitimating their common beliefs; thus they consolidate a collective identity based on the cultural values of the community (Archila and González 2010).

Fifth, in both ontologies, territoriality can result in a relationship between controller and controlled in the territory. Such displacement is defined by Sack (1983: 59) as "it is the law of the land". It implies a pattern of recognition through empirical observation and verification through repetition. While control in indigenous ontologies is verified through local verification, direct experience and qualitative record, Western ontology is grounded in evidence and theory, global/local 
verification and quantitative/qualitative written record (Kawagley and Barnhardt, 1998).

Indigenous ontologies of territoriality differ from Western notions of territoriality in that they acknowledge territory and all creation as both sacred and secular (Reichel-Dolmatoff 1976, Posey 1985, 2002, WinklerPrins and BarreraBassols 2004). Many indigenous ontologies of territoriality recognise a threedimensional interconnection of biophysical, human and mystical levels and embed the sacredness of the uses of the territory (Escobar 2010). Latin American studies on ethnoecology and ethnopedology describe the linkages that traditional inhabitants make between kosmos (belief system and symbolic representations of a local community), corpus (repertory of knowledge or cognitive systems) and praxis (the set of practical operations through which the material appropriation of nature takes place) (Toledo 2002, WinklerPrins and Barrera-Bassols 2004, Reichel-Dolmatoff 1976). This triad (kosmos-corpus-praxis) offers an "integrative approach to the study of the process of human appropriation of nature" (Toledo 2002, 514). An indigenous Colombian Inga describes this collective knowledge as a collective experience in their territory in the following way: "Around the fire in our great home, our spirits dance into a melody of words, we all meet with each other during the Minga (communitarian meeting of indigenous people), in our ancestral territory, weaving together with our original thought, with the hearth and the hands rooted on the legacy of our Law of Origin (Ley de Origen), based on the age-old principles that guide our way of development, of living in our territory, our life in coexistence" (author's translation).

The ontologies on territoriality of Yucuna Matapi Elders in the Amazon region in Colombia interprete river ecosystem characteristics based on their originary law the upich'a world. They appreciate the value of nature regarding all existing species, through the contemplation of the course of their main rivers, based on this they order and plan their territory defining common norms. Under upich'a world, nature in the territory is a living being, and spirits are the natural owners. Their elders delimited their region using rivers which draft its cultural identity as a tree called Karipulaquena (see Graphic 1). They figured it as their master tree, the trunk of the tree is the Amazon river, the main divisions are the Caquetá river and the Miriti river. Alongside the Amazon river there is a second tree, the Cuna river, characterized by the presence of a toxic plant known as barbasquillo, which is why their water course is dark 
(Matapí and Yucuna, 2012). The master tree indicates the broader compression of their territory embedded along the course of these rivers. Elders recall in the storytelling how along the river course there are important resources for their spiritual and material well-being. Along the course nature tells its community how to use these resources long term - for the grandchildren and grandchildren of their grandchildren.

Sack argues that combining the characterizations of reification (fourth overlap above) and displacement (fifth overlap above) could lead to a better understanding of a mystical view of territory; he calls it "a magical perspective" (Sack 1983, 62). It is defined by other authors as "supernatural" and is represented in the indigenous ontologies as open spaces in which spirits are a very real part of the living world. Spiritual beliefs present in local knowledge mediate the ways in which natural resources can be used, supported by village authorities, who act as intermediaries between villagers and local spirits (Löfmarck and Lidskog 2017). In contrast, in Western ontology nature is completely decipherable to the rational human mind and humans dominate the territory and nature in a hierarchical imperative way. From this perspective humans dissect, analyze and manipulate nature for their own benefits (Kawagley and Barnhardt 1998).

Western notions of territoriality have led to a continuous dualism between human and nature, which compartmentalizes territory and reduces it to standard measurements. This approach does not recognise the relational worldviews on territory or indigenous understandings about conservation, productivity and sustainability (Lee 2016, Estermann 1998). Whilst Western land management and planning conceives territory as a delimited area, which contains impersonal relations and uses finite resources to accumulate capital or increase territory itself (Sack 1983, Corson 2011), indigenous communities in the Andes define territory as "Pacha mama", a common good, which must be defended. From the perspective of the Andean nations' collective memory, storytelling and oral histories often communicate a shared story around collective land struggles and their ongoing efforts toward the recuperation of their lands. Land struggles are ignited by a collective fueled by common memory, collective feelings and common roots that allow them to share a communitarian identity around their land (Rappaport 2005). In the words of a Colombian Inga leader, "we are born from the earth. She feeds us. When we die, we go back to the earth. That's why for indigenous people, the earth is the mother. For rich people, earth means only capital" (author's translation). In the words of a 
Colombian Nasa indigenous leader, "there is a common sense that if there is someone killed, this person continues to be alive in all of us. This is the value of the collectivity, of the solidarity: they touch another, it hurts me. This is what has been taught from the stove, since we recovered territories, because we are protected by the spirits" (author's translation). This logic differs from the logic of Western modern rational philosophy in which reality and subjectivity are seen as separate. Human life experience has been reduced to methodological scientific processes focused on a fragmentation of the world (Estermann 1998), indeed modern states are founded upon an individual-citizen/institutional-bureaucracies dichotomy (Anaya 2004, Inman 2015).

Western institutions, particularly state bureaucracies, are not built on a pluralistic understanding of territory, but rather on a definition of territorial monopoly of unitary land and resources, reinforced by national sovereignty (Huebinger and Terwey 2009). Such state monopoly processes have also impacted centralization processes in the majority of Latin American countries (Hartlyn and Valenzuela 1991). This has led to the implementation of coercitive territorial controls that neglected indigenous peoples territoriality, based on the idea that space should be governed by abstract, impersonal and homogenous rules (Vandergeest and Peluso 1995, Sack 1983). State bureaucracies have used territory as a way of generating wealth and territorial expansion, turning territory into an administrative affair and a private or public good that is void of social or cultural relations (Gibson et al. 2000). Table 2 below summarises some characteristics (differences and commonalities) of Western and indigenous ontologies of territoriality.

Table 2: Characteristics of indigenous and Western ontologies of territoriality. Figure adapted from Barnhardt and Kawagley 2005: 16 and Kawagley and Barnhardt 1998: 5 "Figure 2. Qualities associated with traditional (indigenous) knowledge systems and Western science.")

New FILE (added separately)

The Noyuna people, an indigenous group living around the Caquetá River in the Colombian Amazon, offer a good example of indigenous land use that is particularly relevant for a holistic understanding of forests. Whilst the FAO and other 
international organisations monitor forests and their land use by differentiating between forest areas and farms for local or sustenance agriculture, the Noyuna people have, for millennia, managed their territoriality by believing that managing their small subsistence farm (Chagra) equals managing the entire forest (see Picture 1). For them there exists a continuity between the Chagra and the forest. Abel Rodríguez, an elder of the Nonuya, was awarded the 2014 Prince Claus Award from HRH Prince Constantijn for his extensive knowledge of plants. His paintings have been published and disseminated by the NGO Tropenbos (Rodríguez 2014). This work shows the inter-connection of 35 species, including food plants, medicinal plants, animals and humans, in the middle of the forest. The farm is alongside forest, as a symbiosis between Chagra and forest. Whilst large-scale agriculture completely devastates forests, this indigenous group maintains the big trees in parallel to subsistence farming and respects certain times and ranges for cultivating species. They cultivate and collect different products in a cycle lasting 1.5 years, dividing it into 4 different phases, the initial planting, followed by further growth periods of three months, six months, one year and 1.5 years (ibidem).

\section{Applying indigenous ontologies of territoriality to REDD+}

For REDD+, as well as for other conservation mechanisms, cultural values have until now been a secondary consideration in relation to the values associated with nature. Specific 'institutions of knowledge' on territorial management exist across different indigenous traditions, which, at the core, are similar to one another. Whilst indigenous knowledge and territorial knowledge-making are commonly associated with the local level, some argue that elements of it can be expressed as universal knowledge relevant to national and international levels, with the caveat that universalization can imply denying, erasing or suppressing other ways of knowing (Löfmarck and Lidskog 2017, Lee 2016). Even though TEK and ILEK are developed locally, Berkes argues that "many practices are common enough to be called principles; these include rotation of exploited areas and use of territorial systems, as found in different kinds of ecosystems" (Berkes 2012, 180).

Ten years of REDD+ activity has clearly shown that the active participation of local communities improves performance in terms of reducing emissions from deforestation and forest degradation. Global narratives on REDD+ acknowledge uncertainty through national programs, and flexibility exists in the application of 
REDD+ programs to meet local needs. The inclusion of guiding principles of indigenous territoriality such as connectedness and communitarian complementarity thinking in REDD+ policy at national and international levels could enhance channels of dialogue for advancing collective mechanisms of stewardship (guardianship) of forests. Mapping forests promotes a reflective practice on recognizing the connectedness and communitarian complementarity between humans and forests. This can allow REDD+ practitioners to compare the impacts on forests from different forest user groups, understand the value of holistic restoration and avoid compartmentalisation of forest policy. Furthermore, participatory forest management facilitates territorial knowledge sharing among indigenous peoples and supports collective assessments of environmental risks affecting cultural and ecological landscapes, incorporating indigenous rights and enabling communities as qualified partners to co-manage environmental concerns (Robinson et al. 2016).

Based on our analysis of indigenous territoriality, which includes interviews, participant observation and review of literatures, we identify the following three ways in which indigenous territoriality can benefit REDD+ implementation.

(1) Incorporating TEK/ILEK into MRV: Indigenous forest conservation practices can generate quantitative and qualitative data to measure deforestation trends and baselines through local indigenous mapping, which can include details on each specie and each land use practice of a Chagra, which is a traditional indigenous agricultural itinerant cultivation area of the Nonuya as well as other indigenous communities. Indigenous communities manage a Chagra based on the deep knowledge they have developed over millennia. Indigenous farming practices allow land recuperation and soil recovery, thus avoiding erosion (Ibid.). The traditional use of the Chagra recognizes the interaction among multiple species; their crops flourish if they respect all species' attributes and their life cycles (Rodriguez 2013). Indigenous communities manage the Chagra by allowing the area to reforest following restoration activities performed by community members. TEK/ILEK approaches would thus incorporate farmland recuperation into REDD+ projects. Biodiversity and ecosystem services are thus protected, as managing the Chagra is managing the forest.

Remote sensing, and Geographic Information Systems (GIS) as a mapping tool, are already widely used to measure carbon stocks and general characteristics of an area. To complement this, community forest monitoring for REDD+ has been 
found to lower costs, enhance local ownership, increase cultural relevance and improve institutional strength at the community level, while not compromising on accuracy of information produced (Fry 2011). Specifically, TEK/ILEK can contribute methodologies such as mental mapping, visual forms of storytelling and local communities' traditional cartography (made from stories of elders about their territory) to ascertain which forest groups have contribute more to the aims of forest, biodiversity and food security protection in these territories, and how guiding principles and norms of indigenous communities has led to sustainable resources uses in their territories. This not only enables participation in and assures transparency of environmental governance processes, it also reinforces equitable land rights and access to the forest's natural resources (Zurba and Berkes 2014).

(2) Complementary definitions: International organisations differ in their definitions of key terms, including what constitutes a forest, deforestation, forest degradation and forest conservation. Forest definitions also vary from country to country, and within countries at state, regional and local levels (Armenteras et al. 2016). Bionomic models include ecological services of forests at global scale (Clark 2010). These models can be used to reinforce the importance of giving value to indigenous ecological knowledge on forest territoriality also as a cultural ecological heritage for humanity (Rodríguez and González 2017).

In general, forest definitions involve threshold parameters including area, tree height, etc. The FAO forest definition is commonly used and defines a forest as an area with trees over 5 metres in hight and with a coverage of canopy higher than $10 \%$, in areas of more than 0.5 hectares (Angelsen et al. 2009). REDD+ projects have inadvertently exaggerated the role of some species, for example trees over 5 metres, in deforestation and forest degradation (Armenteras et al. 2016). Indigenous territoriality identifies concrete ecological practices that maintain a sustainable forest landscape. Some include a stronger focus on key species that help optimize forest resources. Others include shifting cultivation (swidden) systems and plant gardens that mimic or imitate the diversity of the tropical forest, which is practiced worldwide (Berkes 2012, Redford and Padoch 1992). Ramakrishnan (1992) describes how indigenous farmers optimize the use of soil nutrients by making changes to the crop mixture through changing crop lengths and soil nutrient levels. Yet other practices include land selection, protection of key natural cycles and species, use of droughtresistant and flood-resistant agricultural products and changes in the size of the 
territory according to phases of drought or flood, seed exchange, strengthening of seed banks in situ and spatial redistribution in different landscape units (Shemdoe 2011). These practices move toward a more adaptive and complementary definition of what a fully functioning forest entails.

(3) Co-management agreements and collective benefits: REDD+ payments could be tied to a recognition of indigenous peoples as co-managers of forests through exchanging ecological knowledge and co-creating mechanisms that benefit their territories and their territoriality directly. Over the centuries, indigenous communities in Colombia and Bolivia have developed their own local relationships with territoriality, and their own rules and practices of knowledge formation through principles of communitarian complementarity and connectedness, in isolation from national and international levels. REDD+ could serve as a vehicle for coordinating such adaptive co-management mechanisms that guarantee indigenous peoples custodianship over their forests (Fry 2011), whilst addressing deforestation and forest degradation. Recognizing traditional territorial knowledge and rights of forest communities, through social safeguard provisions of REDD+ projects, have contributed to positive outcomes of community forestry schemes (Harada et al. 2015, Poudel et al. 2014). Global schemes of collective benefits for protecting forests could be adopted taking into account the experiences of inclusive policy-making in Bolivia and Colombia, particularly analyzing the obstacles in the fullfitment of free, prior and informed consent regulations (Nery et al., 2013, Rodriguez, 2014).(Nery et al., 2013, Rodríguez, 2014). In the last few years, Bolivia and Colombia have seen massive mobilisations to avoid extractive activities on indigenous lands, most of them claiming the recognition of indigenous peoples' self-determination (Svampa 2012). Many local groups also reaffirmed their interest in co-management arrangements.

Likewise collective benefit schemes could use the contradictory experiences of Bolivia after 2009 and the constitutional recognition of rights for "Mother Earth". We need to better understand how the recognition of intangible heritages, such as the cultural heritage of Elders and the benefits that nature offers to humans, are valued alongside monetary benefits. In the words of a Bolivian indigenous representative: "Mother Earth thinks in a different way - as a collective subject. Its value is not generated only by people, but by the work of nature. So when a service is produced, the service moves value from the forest to human communities, they benefit from this service. Problem is that we don't pay nature for this service. So an ecological debt is 
generate between people and nature. So we need to pay nature. How? Not with money. But by building the conditions through which nature can rebuild itself" (author's translation).

\section{Conclusion}

Given that knowledge formation is a dynamic process and dependent upon being formed, validated and adapted to changing circumstances both locally and (increasingly) globally, new relationships are needed among indigenous peoples and researchers in order to co-produce knowledge (Berkes 2009). Such relationships require mutual trust and respect in order for both sides to become more open to other kinds of knowledge and knowledge formation processes. Comparing and sharing knowledge across knowledge traditions can create opportunities to develop new methodologies to address deforestation, forest degradation and climate change more generally (Evans et al. 2014).

Much is at stake as we move into the Paris Agreement implementation phase, where 2 or even 1.5 degrees warming thresholds need to be avoided, and where it is clear that this cannot be achieved without the meaningful participation of non-state actors, including indigenous peoples and their unique knowledge base. It is an answer to the call in Article 5 of the Paris Agreement to implement and support "alternative policy approaches, such as joint mitigation and adaptation approaches for the integral and sustainable management of forests, while reaffirming the importance of incentivizing, as appropriate, non-carbon benefits associated with such approaches" (UNFCCC 2015). Applying indigenous ontologies of territoriality to REDD+ also offers opportunities to combine mitigation and adaptation objectives under their objectives REDD+. Linking Indigenous knowledge to REDD+ implementation will increase its efficacy for protecting forests in a more holistic manner, while also respecting the rights of indigenous peoples to maintain their cultural, spiritual and political ties to their traditional territories. In this way, REDD+ could become more aligned with other international conventions seeking to advance the self-determination of indigenous peoples, including the ILO and UNDRIP.

Complementing local with global systems of knowledge formation can improve REDD+ outcomes through incorporating indigenous forest knowledge and developing complementary perspectives with shared cultural values of forest ecosystem services and forest landscapes (Lee 2016, Diver 2017). Further research 
could look into specific applications of TEK/ILEK and indigenous territoriality within REDD+ projects not only in Latin America, but elsewhere too. Such an approach could also be applied to other forms of land use and a broader understanding of forest landscapes.

The three proposed approaches offer avenues for how indigenous territoriality, as a local practice as well as an expression of universal knowledge, could be scaled up and relate to REDD+ across levels of governance. It is an example of how a non-state actors has the capability to extend the leverage of the state (Lövbrand and Linnér 2015, Bulkeley and Schroeder 2012), and thereby effectively contribute to multi-level governance. Approaching REDD+ through the perspective of indigenous territoriality is not only about protecting forests from deforestation and forest degradation, but also about defending the integrity of peoples who have sustainably co-existed in and with their forests by means of a worldview that promotes the well-being of all beings.

\section{Acknowledgements}

This work was supported by the Swedish Research Council under Grant Award No. 421-2011-1862 and Formas under grant award No. 2011-779. This work was also supported by the interinstitutional cooperation agreement between the Political and Social Sciences Department of the University of Bologna (Italy) and the Research Center, University Santo Tomás-Tunja, Colombia, under the grant 'Innovation on Governance in Latin America'.

\section{References}

Abidin, H. (2015). The Protection of Indigenous Peoples and Reduction of Forest Carbon Emissions: The REDD-Plus Regime and International Law. Brill.

Anaya J. 2004. International human rights and Indigenous peoples: the move toward the multicultural state. Arizona journal of international and comparative law. 21:13-61.

Anaya J. 2009. The right of Indigenous peoples to self- determination in the postdeclaration era. In: Chartres C, Stavenhagen R, editors. Making the declaration work: The United Nations Declaration on the Rights of Indigenous peoples. Copenhagen: IWGIA, 184-199. 
Armenteras, D., González, T.M., Retana, J., Espelta, J.M., eds., 2016. Degradación de bosques en Latinoamérica: Síntesis conceptual, metodologías de evaluación y casos de estudio nacionales (Forest degradation in Latin America: summary, evaluation methodology and national case studies). IBERO-REDD+ Network.

Arts, B., Behagel, J.H., Van Bommel, S., De Koning, J. (Eds.), 2013. Forest and Nature Governance - A Practice-based Approach. World Forests Series. Heidelberg: Springer.

Angelsen, A., Brockhaus, M., Sunderlin, W.D. and Verchot, L.V. eds., 2012. Analysing REDD+: Challenges and choices. Bogor: CIFOR.

Archila, M., González, N. C., 2010. Movimiento Indígena caucano: historia y política (Cauca Indigenous Movement: History and Politics). Santo Tomás University Press.

Barnhardt, R. (2005). Indigenous knowledge systems and Alaska Native ways of knowing. Anthropology \& education quarterly, 36(1), 8-23.

Berkes, F., 2012. Sacred Ecology, 3rd ed. New York and London: Routledge.

Berkes, F., 2009. Indigenous ways of knowing and the study of environmental change, Journal of the Royal Society of New Zealand, 39 (4), 151-156.

Betts, H., Schroeder H., 2015. Multi-stakeholder governance. In: K. Bäckstrand and E. Lövbrand., eds., Research Handbook on Climate Governance. Cheltenham, UK: Edward Elgar, 377-387.

Biermann, F., Betsill, M., Camargo Vieira, S., Gupta, J., Kanie, N., Lebel, L., Liverman, D., Schroeder, H., Siebenhuener, B., Yanda, P.Z., Zondervan, R., 2010. Navigating the Anthropocene: The Earth System Governance Project Strategy Paper, Current Opinion in Environmental Sustainability, 2 (3), 202208.

Brockhaus, M., Di Gregorio, M., Carmenta, R., 2014. REDD+ policy networks: exploring actors and power structures in an emerging policy domain. Ecology and Society, 19 (4), 29.

Bulkeley, H., Schroeder, H., 2012. Beyond State and Non-state Divides: Global Cities and the Governance of Climate Change. European Journal of International Relations, 18 (4), 743-66.

Butzier, S. R., Stevenson, S. M., 2015. Indigenous Peoples' Rights to Sacred Sites and Traditional Cultural Properties and the Role of Consultation and Free, Prior and Informed Consent. Journal of Energy \& Natural Resources Law, 32 (3), 297-334.

Cabello, J, Gilbertson, T., 2012. A colonial mechanism to enclose lands: A critical review of two REDD+-focused special issues. ephemera, 12 (1-2), 162-180.

Cabildo Indígena de Jambaló (Indigenous Council of Jambaló), 2006. Ordenamiento y servicio jurídico del territorio (Territorial legal management service). Escué Alcibíades y Junta directiva de la Vereda Natalá 2002- 2005. Resguardo indígena de Jambaló.

Chapman, S., Wilder, M., Millar, I., 2014. Defining the Legal Elements of Benefit Sharing in the Context of REDD. Carbon \& Climate Law Review, CCLR, 8, (4): 270-81. 
Chao, S., 2012. Forest peoples: numbers across the world. Moreton-in-Marsh: Forest Peoples Programme.

Clark, C. W., 2010. Mathematical bioeconomics: the mathematics of conservation (Vol. 91). John Wiley \& Sons.

Corbera, E., Schroeder, H. 2017. REDD+ Crossroads Post Paris: Politics, Lessons and Interplays, Forests 8 (12), 508.

Corbera, E., Schroeder, H., 2011. Governing and implementing REDD+, Environmental Science \& Policy, 14 (2), 89-100.

Corson, C., 2011. Territorialization, enclosure and neoliberalism: non-state influence in struggles over Madagascar's forests. Journal of Peasant Studies, 38 (4), 703726.

Craig, D., 2015. 17. Legal strategies to expand indigenous governance in climate change adaptation. The Search for Environmental Justice, 309.

Davis, C. Daviet F. Nakhooda, S., Thuault, A., 2009. A Review of 25 Readiness Plan Idea Notes from the World Bank Forest Carbon Partnership Facility [online]. WRI Working Paper. Washington DC: http://www.wri.org/gfi. [Accessed 17.06.16].

Dehm, J., 2016. Indigenous peoples and REDD+ safeguards: rights as resistance or as disciplinary inclusion in the green economy?, Journal of Human Rights and the Environment, 7 (2), 170-217.

Deloria, V., 1969. Custer died for your sins: An Indian manifesto. University of Oklahoma Press.

Diver, S. (2017). Negotiating Indigenous knowledge at the science policy-interface: Insights from the Xáxli’p Community Forest. Environmental Science \& Policy, $73,1-11$.

Escobar, A., 2010. Unlike territories, Location, movements, networks, life. Spanish version. Popayán: Samava Printers.

Estermann, J., 1998. Filosofía Andina, estudio intercultural de la sabiduría autóctona andina (Andean philosophy, cultural study of Andean indigenous knowledge). Quito: Abya Yala Press.

Evans K., Murphy L., Jong d. W. 2014. Global versus local narratives of REDD: a case study from Peru's Amazon. Environmental Science \& Policy, 35, 98-108

Fox-Decent, E., Dahlman, I., 2015. Sovereignty as Trusteeship and Indigenous Peoples. Theoretical Inquiries in Law, 16(2), 507-534.

Fry, B.P., 2011. Community forest monitoring in REDD+: the ' $M$ ' in MRV?, Environmental Science \& Policy, 14 (2), 181-187.

Gibson, C., McKean M., Ostrom E. 2000. People and Forest, Communities, Institutions and Governance. MIT Press: Cambridge.

Gilbert, J., 2006. Indigenous Peoples' Land Rights under International Law. Transnational Publishers.

Gilberthorpe, E., Rajak, D., 2017. The anthropology of extraction: Critical perspectives on the resource curse, Journal of Development Studies, 53, 186204. 
Glover, A., H. Schroeder (2017), Legitimacy in REDD+ Governance in Indonesia, International Environmental Agreements: Politics, Law and Economics. doi:10.1007/s10784-016-9341-x.

González, N.C., 2011. Institucionalización y Movilización ¿Dos caminos divergentes en la democratización indígena? (Institutionalization and Mobilization: Two Diverging Pathways in Indigenous Democratization). Revista América Latina Hoy, 59, 71-90.

Gómez-Baggethun, E., E. Corbera., V. Reyes-García., 2013. Traditional ecological knowledge and global environmental change: research findings and policy implications. Ecology and Society, 18 (4), 72-80.

Griffiths, T., 2008. Seeing 'REDD' - Avoided deforestation and the rights of indigenous peoples and local communities. Indigenous Perspectives, 9 (1-2), 93-118.

Gross, C., Foyer, J., eds., 2010. ¿Desarrollo con identidad? Gobernanza económica indígena, siete estudios de caso (Development with identity? Indian economic governance, seven case studies). Quito: FLACSO.

Gupta, A., Pistorius, T., Vijge, M.J., 2016. Managing fragmentation in global environmental governance: the REDD+ Partnership as bridge organisation. International Environmental Agreements: Politics, Law and Economics, 16 (3), 355-374.

Hall, R., ed., 2013. REDD+ and the Underlying Causes of Deforestation and Forest Degradation. Global Forest Coalition.

Hanna, P., Vanclay, F., 2013. Human rights, indigenous peoples and the concept of free, prior and informed consent. Impact Assessment and Project Appraisal, 31(2), 146-157.

Harada, K., Prabowo, D., Aliadi, A., Ichihara, J., Ma, H. O. (2015). How Can Social Safeguards of REDD+ Function Effectively Conserve Forests and Improve Local Livelihoods? A Case from Meru Betiri National Park, East Java, Indonesia. Land, 4 (1), 119-139.

Hartlyn, J., Valenzuela, A., 1991. La democracia en América Latina desde 1930 (Democracy in Latin America since 1930). In: Bethell L. Historia de América Latina, 12, Cambridge and Barcelona: University Press-Crítica, 11-63.

Holmes, G., 2014. Defining the forest, defending the forest: political ecology, territoriality, and resistance to a protected area in the Dominican Republic. Geoforum, 53, 1-10.

Huebinger G., Terwey. A. 2009. Max Weber Allgemeine Staatslehre und Politik (Staatsoziologie). Mit und Nachschriften 1920. Tuebingen: J.C.B. Mohr (Paul Siebeck).

Inman, D. M. K. 2015. From the Global to the Local: The Development of Indigenous Peoples' Land Rights Internationally and in Southeast Asia. Asian Journal of International Law, 43.

ILO, 2013. Understanding the Indigenous and Tribal Convention, 1989 (No. 169). ILO Geneva. 
Kawagley, A.O., Barnhardt, R., 1998. Education indigenous to place: Western science meets native reality.

Kovach, M., 2010. Indigenous methodologies: Characteristics, conversations, and contexts. University of Toronto Press.

Krause, T., Collen, W., Nicholas, K.A., 2013. Evaluating safeguards in a conservation incentive program: participation, consent, and benefit sharing in indigenous communities of the Ecuadorian Amazon. Ecology and Society, 18 (4), 1.

Krott, M., Giessen, L., 2014. Learning from practices-implications of the "practice based approach" for forest and environmental policy research. Forest Policy and Economics, 49, 12-16.

Kohn E., 2013. How Forests Think: Toward an Anthropology Beyond the Human. University of California Press.

Lajó, J., 2006. Qhapaq Ñan: La ruta de la sabiduría Inca (Qhapaq Ñan: The route of the Inca wisdom). Quito: Ediciones Abya Yala.

Lee, E., 2016. Protected Areas, Country and Value: The Nature-Culture Tyranny of the Iucn's Protected Area Guidelines for Indigenous Australians, Antipode, 48 (2), 355-74.

Löfmarck, E., Lidskog, R. (2017). Bumping against the boundary: IPBES and the knowledge divide. Environmental Science \& Policy, 69, 22-28.

Lövbrand, E., Linnér, B.-O., 2015. Governing beyond or with the state? State conceptions in studies on non-state climate action. In Kronsell, A. and Bäckstrand, K. (eds.) Rethinking the state: environmental governance towards climate and sustainability transitions, Routledge.

Luttrell, C., Loft, L., Gebara, M.F., Kweka, D., Brockhaus, M., Angelsen, A., Sunderlin, W.D., 2013. Who should benefit from REDD+? Rationales and realities. Ecology and Society, 18 (4), 52.

Luttrell, C., Resosudarmo, A.P., Muharrom, E., Brockhaus, M., Seymour, F., 2014. The political context of REDD+ in Indonesia: Constituencies for change. Environmental Science and Policy, 35, 67-75.

Matapí, U., Yucuna, R., 2012. Cartografia ancestral yucuna-matapí: conocimiento y manejo tradicional del territorio. Proyecto Cartografía cultural del noreste amazónico. Ministerio de Cultura, Patrimonio Natural- Fondo para la Biodiversidad y Áreas Protegidas en alianza con Tropenbos Internacional Colombia. Bogotá, 2012.

McDermott, C. L., Ituarte-Lima. C., 2016. Safeguarding what and for whom? The role of institutional fit in shaping REDD+ in Mexico. Ecology and Society, 21 (1), 9.

McDermott, C., Coad, L., Helfgott, A., Schroeder, H., 2012. Operationalizing social safeguards in REDD+: Actors, interests and ideas. Environmental Science \& Policy, 21, 63-72.

McGregor, D., 2002. Indigenous knowledge in sustainable forest management: Community-based approaches achieve greater success. The forestry chronicle, 78(6), 833-836. 
McGregor, D., 2011. Aboriginal/non-Aboriginal relations and sustainable forest management in Canada: The influence of the Royal Commission on Aboriginal Peoples. Journal of Environmental Management, 92(2), 300-310.

Mulyani, M., Jepson, P., 2013. REDD+ and Forest Governance in Indonesia: A Multi-stakeholder Study of Perceived Challenges and Opportunities. The Journal of Environment Development, 22 (2), 1-23.

Nadasdy, P., 2005. The anti-politics of TEK: The institutionalization of comanagement discourse and practice. Anthropologica, 47 (2), 215-232.

Nasiritousi, N., Hjerpe, M., Linnér, B.-O., 2016. The roles of non-state actors in climate change governance: understanding agency through governance profiles. International Environmental Agreements: Politics, Law and Economics, 16 (1), 109-126.

Newell, P., Pattberg, P., Schroeder, H., 2012. Multiactor Governance and Environment, Annual Review of Environment and Resources, 37, 365-87.

Ortega, R.R., 200). Pueblos indígenas y leyes en Colombia: aproximación crítica al estudio de su pasado y su presente. Gaia Foundation.

Osborne, T., Bellante, L., von Hedemann, N., 2014. Indigenous Peoples and REDD+: A Critical Perspective. Indigenous People's Biocultural Climate Change Assessment Initiative.

Papyrakis, E., Rieger, M., Gilberthorpe, E., 2017. Corruption and the extractive industries transparency initiative. Journal of Development Studies, 53, 295-309.

Peluso, N.L., 1996. Fruit trees and family trees in an anthropogenic forest: Ethics of access, property zones, and environmental change in Indonesia. Comparative studies in Society and History, 38 (3), 510-548.

Perrin, J. (2018). Kollektive Landrechte indigener Völker Lateinamerikas. Vom Menschenrecht auf Eigentum zu indigener Souveränität?. Von der Allmende zur Share Economy: Gemeinbesitz und kollektive Ressourcen in historischer und rechtlicher Perspektive, 15, 281.

Posey, D. A. 1985. Indigenous management of tropical forest ecosystems: the case of the Kayapó indians of the Brazilian Amazon. Agroforestry System, 3 (2), 139158.

Posey, D. A. 2002. Upsetting the sacred balance: Can the study of indigenous knowledge reflect connectedness?. In: P. Sillitoe, A. Bicker and J. Pottier (eds.), Participating in Development: Approaches to Indigenous Knowledge. London/New York: Routledge, 24- 42.

Poudel, M., Thwaites, R., Race, D., Dahal, G. R., 2014. REDD+ and community forestry: implications for local communities and forest management-a case study from Nepal. International Forestry Review, 16 (1), 39-54.

Ramakrishnan, P. S. 1992. Shifting agriculture and sustainable development: an interdisciplinary study from north-eastern India. Parthenon Publishing Group.

Rappaport, J., 2005. Cumbe reborn: an Andean ethnography of history. Spanish version. Bogota: ICANH.

Redford, K. H., \& Padoch, C. 1992. Conservation of neotropical forests: working from traditional resource use. Columbia University Press. 
Reichel-Dolmatoff, G., 1976. Cosmology as ecological analysis: A view from the rainforest. Man (N.S.), 11 (3), 307-318.

Robinson, C. J., Maclean, K., Hill, R., Bock, E., Rist, P. 2016. Participatory mapping to negotiate indigenous knowledge used to assess environmental risk. Sustainability Science, 11 (1), 115-126.

Rodríguez G.A. and González, N.C., 2017. "Institutional limits in the consolidation of an environmental governance in protected areas, the case of Yaigoje Apaporis in the Colombian Amazonia". 4th Congress of Latin American Faculty on Social Sciences, FLACSO. July, Salamanca, Spain.

Sack, R. D., 1983. Human Territoriality: A Theory. Annals of the Association of American Geographers, 73 (1), 55-74.

Salick, J., Byg, A., 2007. Indigenous Peoples and Climate Change, Report of Symposium 12-13.04.07, Tyndall Centre.

Sato, T., 2014. Integrated Local Environmental Knowledge Supporting Adaptive Governance of Local Communities. In: Alvares, C. ed., Multicultural Knowledge and the University, Multiversity India, 268-273.

Shedoe, R. S., (2011). Tracking Effective Indigenous Adaptation Strategies on Impacts of Climate Variability on Food Security and Health of Subsistence Farmers in Tanzania. Research paper, N.4. ATPS.

Tuhiwai Smith, L., 2013. Decolonizing methodologies: Research and indigenous peoples. Zed Books.

Sobrevila, C. 2008. The Role of Indigenous Peoples in Biodiversity Conservation: The Natural but Often Forgotten Partners. Washington, D.C.: IBRD.

Thompson, M., Baruah, M., Carr. E., 2011. Seeing REDD+ as a project of environmental governance. Environmental Science \& Policy, 14, 100-110.

Toledo, V. M. 2002. Ethnoecology: A conceptual framework for the study of indigenous knowledge on nature. In J. R. Stepp, F. S. Wyndham, and R. Zarger (eds.), Ethnobiology and Biocultural Diversity: Proceedings of the Seventh International Congress of Ethnobiology. Athens: University of Georgia Press, 511-522.

Turnhout, E., Dewulf, A., Hulme, M., 2016. What does policy-relevant global environmental knowledge do? The cases of climate and biodiversity. Current Opinion in Environmental Sustainability, 18, 65-72.

Van Cott, D. L., 2000. The Friendly Liquidation of the Past. The Politics of Diversity in Latin America. Pittsburgh: University of Pittsburgh Press.

Vandergeest, P., Peluso, N.L., 1995. Territorialization and State Power in Thailand. Theory and Society, 24 (3), 385-426.

Vieco, J. J., Franky, C. E., Echeverri J. Á. (Eds), 2000. Territorialidad indígena y ordenamiento en la Amazonia. Bogotá: UNAL.

Wallbott, L., 2014. Indigenous peoples in UN REDD+ negotiations: "importing power" and lobbying for rights through discursive interplay management. Ecology and Society, 19 (1), 21.

WinklerPrins, A., Barrera-Bassols, N. 2004. Latin American ethnopedology: A vision of its past, present, and future. Agriculture and Human Values 21, 139-156. 
Zhang, K., et al., 2015. The fate of Amazonian ecosystems over the coming century arising from changes in climate, atmospheric $\mathrm{CO} 2$, and land use. Global Change Biology, 21, 2569-2587.

Zurba, M., Berkes, F., 2014. Caring for country through participatory art: creating a boundary object for communicating Indigenous knowledge and values. Local Environment, 19 (8), 821-836. 